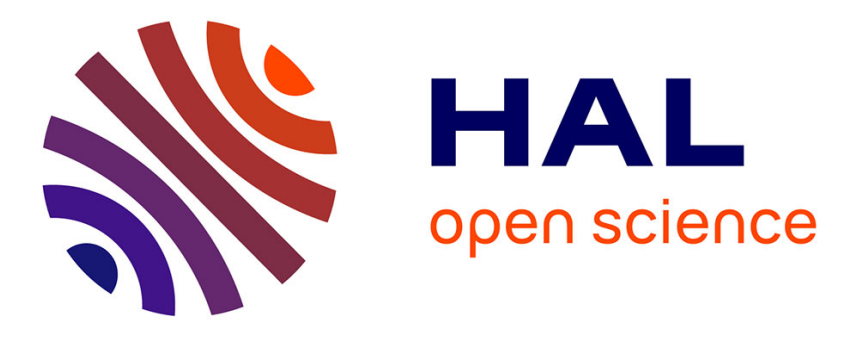

\title{
Blind-prediction: estimating the consequences of vented hydrogen deflagrations for homogeneous mixtures in 20-foot iso containers
}

T. Skjold, H. Hisken, S. Lakshmipathy, G. Atanga, M.N. Carcassi, M. Schiavetti, J.R. Stewart, A. Newton, J.R. Hoyes, I.C. Tolias, et al.

\section{To cite this version:}

T. Skjold, H. Hisken, S. Lakshmipathy, G. Atanga, M.N. Carcassi, et al.. Blind-prediction: estimating the consequences of vented hydrogen deflagrations for homogeneous mixtures in 20-foot iso containers. 7. International conference on hydrogen safety (ICHS 2017), Sep 2017, Hambourg, Germany. pp.639652. ineris-01863241

\section{HAL Id: ineris-01863241 \\ https://hal-ineris.archives-ouvertes.fr/ineris-01863241}

Submitted on 28 Aug 2018

HAL is a multi-disciplinary open access archive for the deposit and dissemination of scientific research documents, whether they are published or not. The documents may come from teaching and research institutions in France or abroad, or from public or private research centers.
L'archive ouverte pluridisciplinaire HAL, est destinée au dépôt et à la diffusion de documents scientifiques de niveau recherche, publiés ou non, émanant des établissements d'enseignement et de recherche français ou étrangers, des laboratoires publics ou privés. 


\title{
BLIND-PREDICTION: ESTIMATING THE CONSEQUENCES OF VENTED HYDROGEN DEFLAGRATIONS FOR HOMOGENEOUS MIXTURES IN 20-FOOT ISO CONTAINERS
}

\author{
Skjold, T. ${ }^{1}$, Hisken, H. ${ }^{1}$, Lakshmipathy, S. ${ }^{1}$, Atanga, G. ${ }^{1}$, Carcassi, M. $^{2}$, Schiavetti, M. ${ }^{2}$, \\ Stewart, J.R. ${ }^{3}$, Newton, A. ${ }^{3}$, Hoyes, J.R. ${ }^{3}$, Tolias, I.C. ${ }^{4}$, Venetsanos, A.G. ${ }^{4}$, Hansen, O.R. ${ }^{5}$, \\ Geng, J. ${ }^{6}$, Huser, A. ${ }^{7}$, Helland, S. ${ }^{8}$, Jambut, R. ${ }^{9}$, Ren, K. ${ }^{10}$, Kotchourko, A. ${ }^{10}$, Jordan, T. ${ }^{10}$, \\ Daubech, J. ${ }^{11}$, Lecocq, G. ${ }^{11}$, Hanssen, A.G. ${ }^{12}$, Kumar, C. ${ }^{13}$, Krumenacker, L. ${ }^{14}$, \\ Jallais, S. ${ }^{15}$, Miller, D. ${ }^{16}$ and Bauwens, C.R. ${ }^{17}$ \\ ${ }^{1}$ Gexcon, Fantoftvegen 38, 5072 Bergen, Norway, trygve@gexcon.com \\ ${ }^{2}$ University of Pisa, Largo Lucio Lazzarino 2, 56122 Pisa, Italy, m.carcassi@ing.unipi.it \\ ${ }^{3}$ HSE, Harpur Hill, Buxton, Derbyshire, SK17 9JN, UK, james.stewart@hsl.gsi.gov.uk \\ ${ }^{4}$ Environmental Research Laboratory, National Center for Scientific Research \\ Demokritos, Agia Paraskevi, 15310, Greece, tolias@ipta.demokritos.gr \\ ${ }^{5}$ Lloyd's Register, Kokstadflaten 35, 5863 Bergen, Norway, olav.hansen@1r.org \\ ${ }^{6}$ Baker Risk, 3330 Oakwell Court, San Antonio, TX, jgeng@bakerrisk.com \\ ${ }^{7}$ DNV GL, Veritasveien 1, 1337 Høvik, Norway, asmund.huser@dnvgl.com \\ ${ }^{8}$ DNV GL, Thormolens gate 49A, 5006 Bergen, Norway, sjur.helland@dnvgl.com \\ ${ }^{9}$ DNV GL, 69 Rue Chevaleret, 75014 Paris, France, romain.jambut@dnvgl.com \\ ${ }^{10}$ Karlsruhe Institute of Technology, 76131 Karlsruhe, Germany, ke.ren@kit.edu \\ ${ }^{11}$ INERIS, BP 2, 60550Verneuil-en-Halatte, France, guillaume.lecocq@ineris.fr \\ ${ }^{12}$ IMPETUS Afea, Strandgaten 32, 4400 Flekkefjord, Norway, arve@impetus.no \\ ${ }^{13}$ Fluidyn, 146 Ring Road, Bangalore 560102, India, chenthil.kumar@,fluidyn.com \\ ${ }^{14}$ Fluidyn, 7 Blvd. de la Libération, 93200 Saint-Denis, France, laurent.krumenacker@fluidyn.com \\ ${ }^{15}$ Air Liquide R\&D, Paris-Saclay, BP 126, 78354, Jouy-en-Josas, France, simon.jallais@airliquide.com \\ ${ }^{16}$ Air Products, 7201 Hamilton Boulevard, Allentown, PA 18195-1501, millerd3@airproducts.com \\ ${ }^{17}$ FM Global, 1151 Boston-Providence Turnpike, Norwood 02062, MA, carl.bauwens@,fmglobal.com
}

\begin{abstract}
This paper summarises the results from a blind-prediction study for models developed for estimating the consequences of vented hydrogen deflagrations. The work is part of the project Improving hydrogen safety for energy applications through pre-normative research on vented deflagrations (HySEA). The scenarios selected for the blind-prediction entailed vented explosions with homogeneous hydrogen-air mixtures in a 20 -foot ISO container. The test program included two configurations and six experiments, i.e. three repeated tests for each scenario. The comparison between experimental results and model predictions reveals reasonable agreement for some of the models, and significant discrepancies for others. It is foreseen that the first blind-prediction study in the HySEA project will motivate developers to improve their models, and to update guidelines for users of the models.
\end{abstract}

\section{INTRODUCTION}

\subsection{The HySEA project}

Fires and explosions represent a significant hazard for hydrogen installations, and specific measures are generally required for reducing the risk to a tolerable level [1]. To this end, it is important to validate and improve the models used for assessing the potential consequences of accident scenarios. Explosion venting is a frequently used measure for reducing the consequences of deflagrations in confined systems. The main objective of the HySEA project (www.hysea.eu) is to develop recommendations for improved international standards for the design of explosion venting devices, such as EN 14994 [2] and NFPA 68 [3]. The members of the HySEA consortium are Gexcon (coordinator), University of Warwick (UWAR), University of Pisa (UNIPI), Fike Europe, Impetus Afea and Hefei University of Technology (HFUT). This paper describes the first of two blind-prediction studies in the HySEA project. The results from these studies represent valuable input for the development and validation of engineering models (EMs), as well as computational fluid dynamics (CFD) and finite element (FE) models. 


\subsection{Previous work}

Vented hydrogen deflagrations have been extensively studied in the past, but primarily for empty enclosures. The experiments conducted by Sommersel et al. in a 20-foot ISO container [6-7], with varying degrees of congestion, resemble the work presented here. However, these experiments involved ignition of transient releases, and are therefore more relevant for the second experimental campaign in the HySEA project, which will focus on scenarios with initial turbulence and inhomogeneous gas clouds. Several blind-prediction or benchmark studies have been conducted for hydrogen in the past [e.g. 8-11].

\subsection{The first HySEA blind-prediction study}

The HySEA consortium invited researchers and engineers to submit model predictions for two welldefined explosion scenarios prior to the completion of the actual experiments. The registration deadline for participation in the first blind-prediction study was 12 August 2016, and the submission deadline for model results was 2 September 2016. The entire test program with homogeneous mixtures (Phase 1) in 20-foot ISO containers included 34 tests [6-7]. The scenarios selected for the blind-prediction involved explosions in initially homogeneous and quiescent clouds of $15.0 \pm 0.2 \mathrm{vol} . \%$ hydrogen in air, with or without an obstacle inside the container, and three repetitions for each scenario. University of Pisa collected the model predictions, and Gexcon organized the first HySEA Demo at the Gexcon test site on the island of Sotra outside Bergen on 8 September 2016, and the first HySEA Workshop in Bergen on 9 September 2016. The Demo featured four live demonstration experiments with vented hydrogen deflagrations in containers, including the two scenarios from the blind-prediction study. The Workshop included a preliminary comparison of the model predictions and experimental results.

\section{EXPERIMENTS}

\subsection{Experimental setup}

Figure 1 illustrates the two scenarios selected for the blind-prediction study: a 20-foot ISO container with open doors, with or without a bottle basket with twenty 50-litre high-pressure cylinders. Gexcon performed the experiments at the remote test site on the island of Sotra outside Bergen during September 2016. Figure 2 shows the test site, with one of the containers ready for testing.
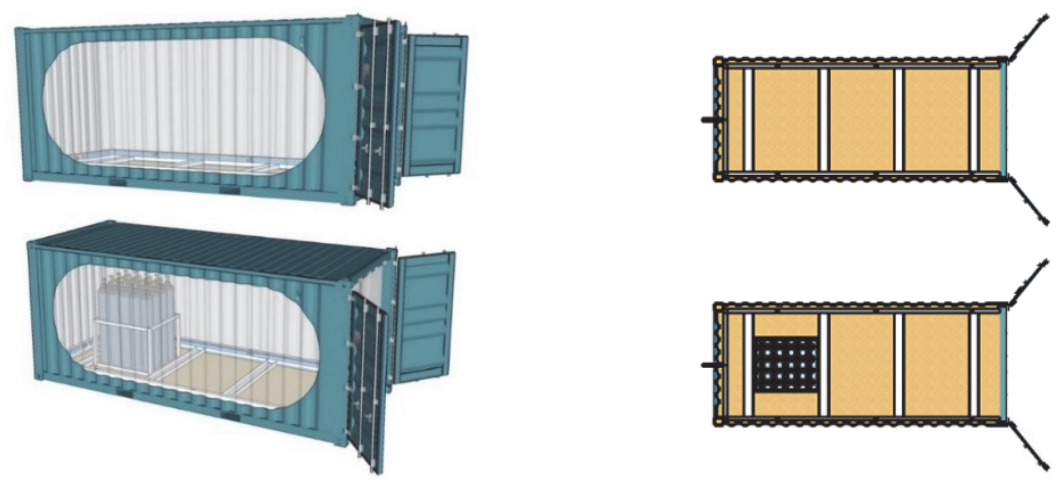

Figure 1: Empty container (above) and container with bottle basket obstacle (below).

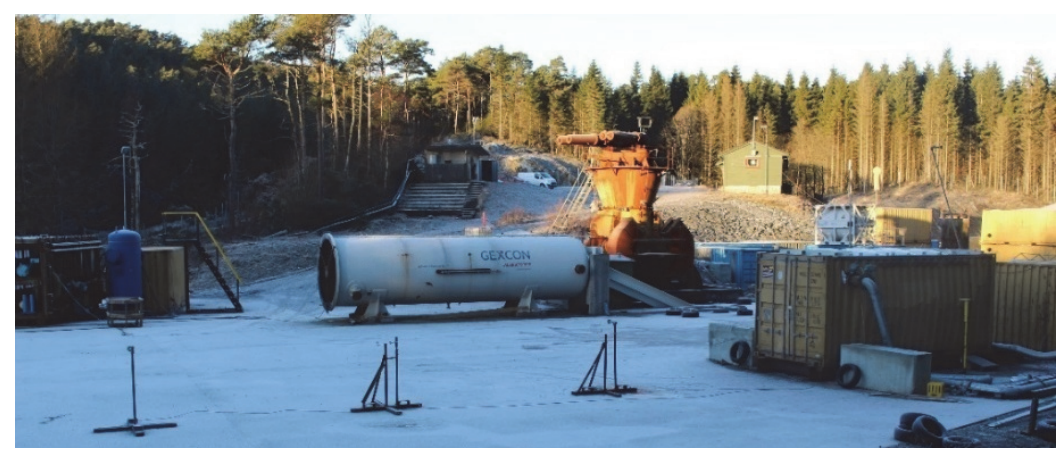

Figure 2: Test site with a 20-foot container and supports for the three external pressure sensors. 
The experimental setup consisted of a standard 20-foot ISO container, fitted with a steel frame for instrumentation and obstacle support. Figure 3 shows the container, and Figure 4 summarises the main dimensions of the container. The floor of the container is covered with plywood, and the walls and roof are made of $2 \mathrm{~mm}$ thick corrugated steel plates. The depth of the corrugations in the wall and roof are about 35 and $16 \mathrm{~mm}$, respectively.
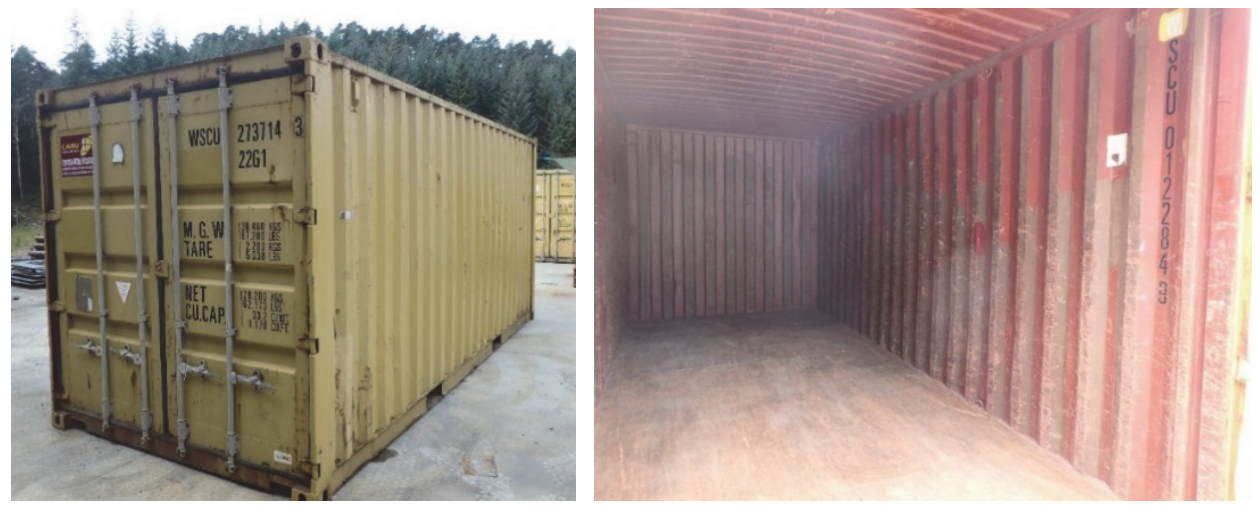

Figure 3: The 20-foot container (left) and the interior of the container (right).
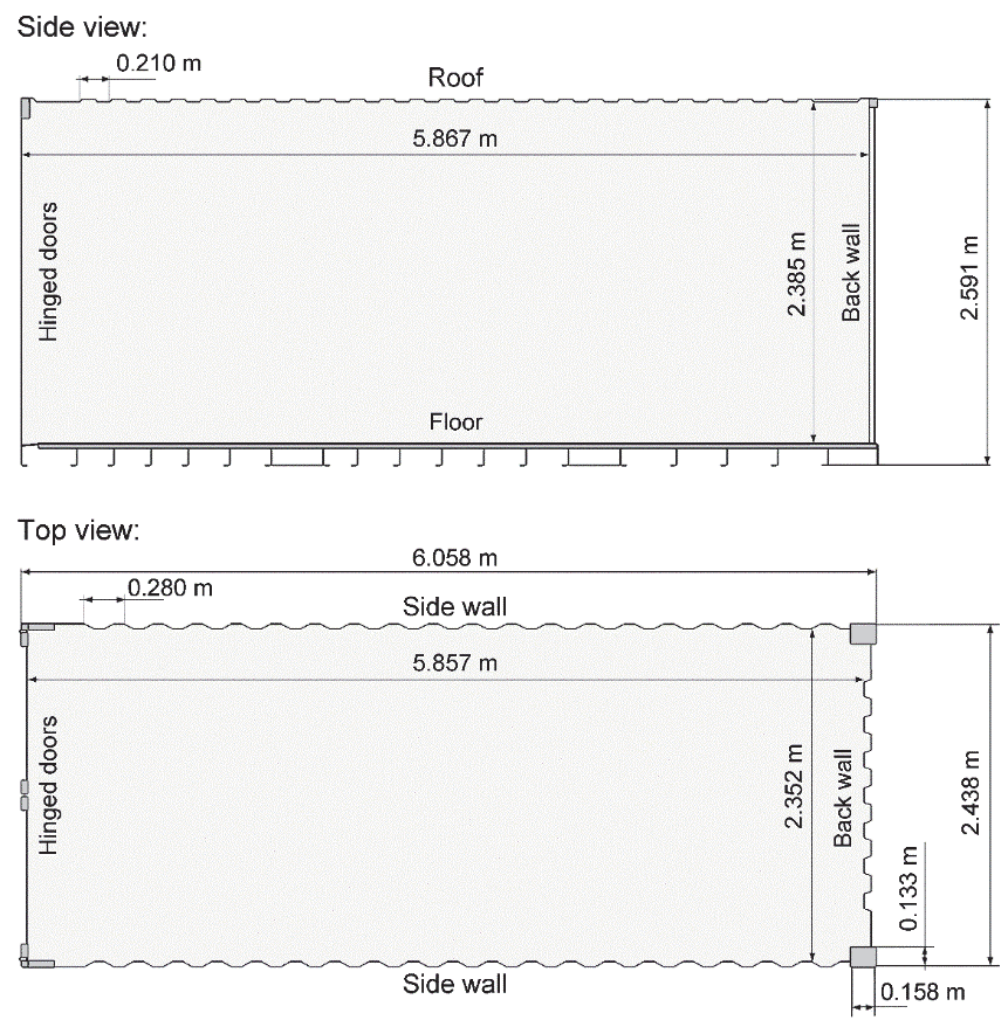

Figure 4: Dimensions of the container.

Figure 5 shows the steel frame that protected the internal pressure transducers (P01-P08) and signal cables, and supported the obstacle. The frame was constructed from $200 \mathrm{~mm} \times 75 \mathrm{~mm}$ U-beams (UNP). The container was placed on a foundation made from two $360 \mathrm{~mm}$ H-beams, i.e. the bottom of the containers was positioned $0.36 \mathrm{~m}$ above ground level during testing. The container was fixed to the foundation by four bolts along each side of the container, passing through the steel frame. This was necessary to prevent significant movement of the containers during testing, which could damage parts of the measurement system. Figure 6 shows the bottle basket obstacle, and Figure 7 shows a container prepared for testing, with both doors open and a $0.2 \mathrm{~mm}$ polyethylene sheet used as a vent cover $(99 \%$ polyethylene, specific weight $0.185 \mathrm{~kg} \mathrm{~m}^{-2}$ ). 

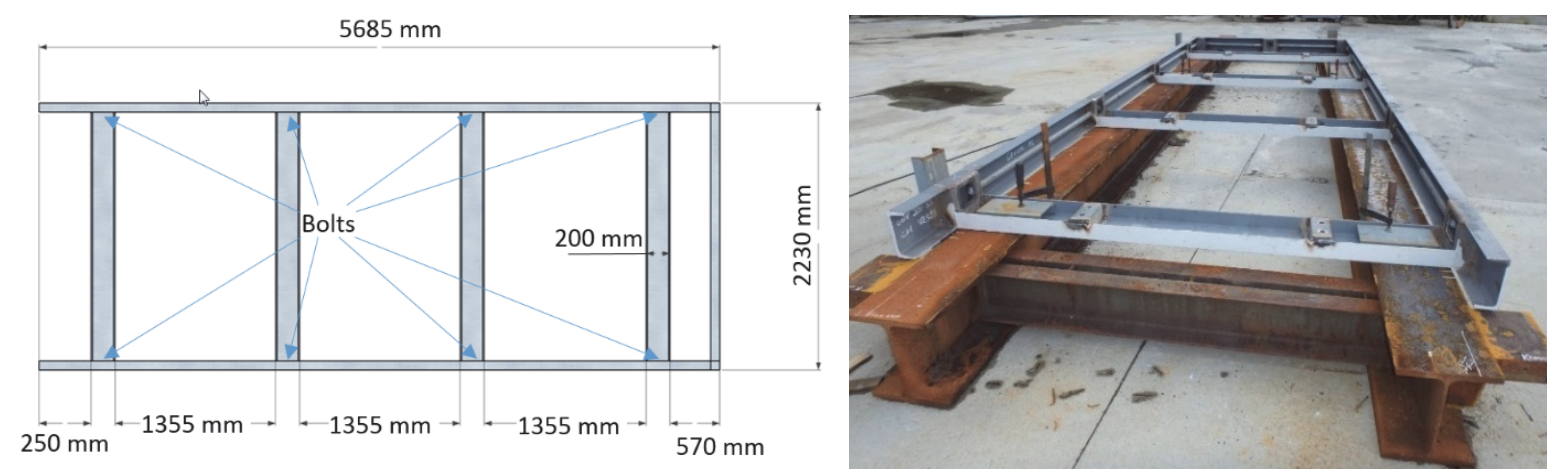

Figure 5. Dimensions of steel frame (left) and steel frame positioned on foundation (right).
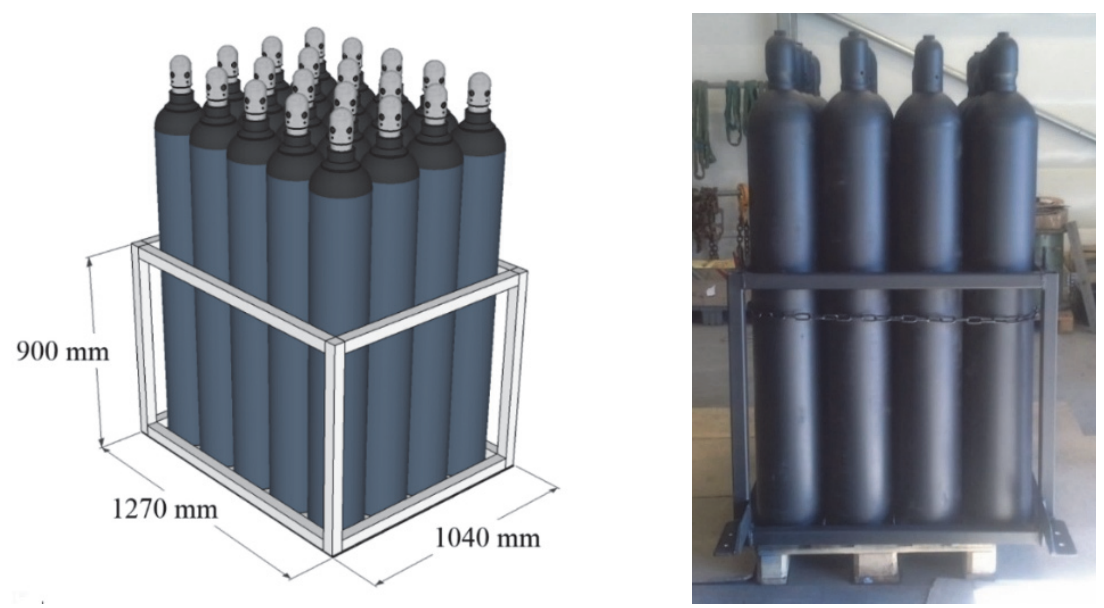

Figure 6. Dimensions of bottle basket (left) and basket with 50-litre high-pressure cylinders (right).

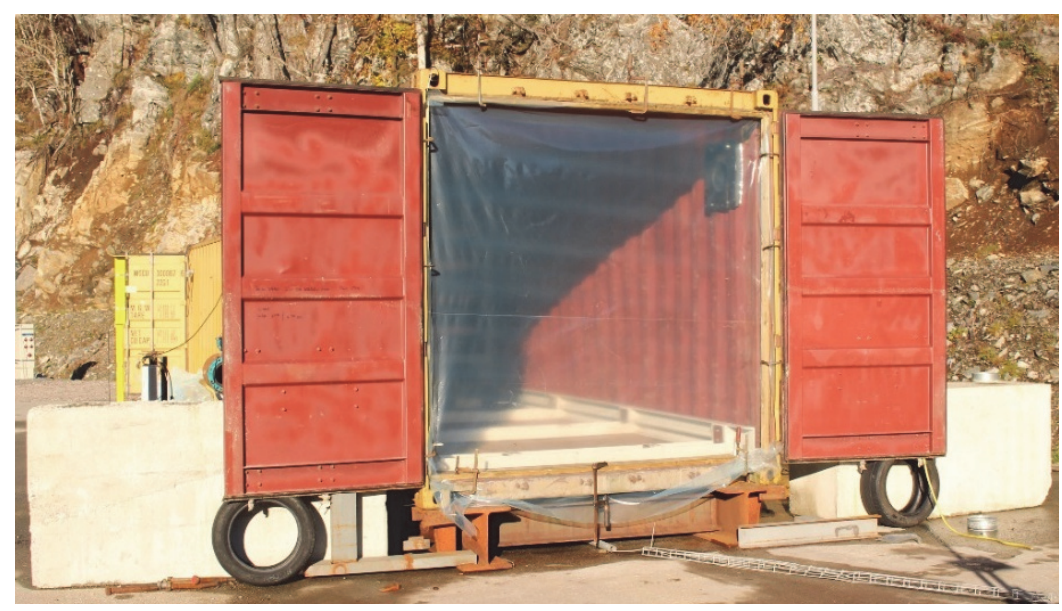

Figure 7: Container doors in fully open position, and opening covered by a polyethylene sheet.

\subsection{Flammable mixture and ignition}

A recirculation system was used to prepare homogeneous hydrogen-air mixtures inside the container. To eliminate the effect of initial turbulence, the explosive atmosphere was isolated from the recirculation system by closing remotely operated valves prior to ignition. A Servomex Xendos 2223 oxygen analyser measured the gas concentration in the recirculation system and at selected points inside the container up to the moment of ignition. The ignition source was an electric inductive spark discharge, energy about $1 \mathrm{~mJ}$, triggered at a specific time. The spark plug was located at the back wall of the container at midheight, i.e. about $1.2 \mathrm{~m}$ above the floor (referred to as ignition position A). 


\subsection{Measurement system and data processing}

Figure 8 illustrates the position of the pressure and displacement sensors. Eight Kistler 701A/7031 piezoelectric pressure sensors with Kistler 5073A211 charge amplifiers measured internal pressures in positions P01-P08 inside the container, and three Kistler 4043A piezoresistive pressure gauges with Kistler 4601 amplifiers measured the far-field blast pressures in positions P09-P11. The internal pressure sensors were positioned at the U-beams, along the side walls of the container, in the same position as the eight bolts fixing the frame to a solid foundation underneath the container $(0.805,2.355,3.905$ and $5.455 \mathrm{~m}$ from the back wall), $85 \mathrm{~mm}$ from the side wall, and $200 \mathrm{~mm}$ above the floor (blue arrows in Figure 5). Figure 2 shows the holders for the external pressure sensors P09-P11, located $5 \mathrm{~m}, 10 \mathrm{~m}$ and $15 \mathrm{~m}$ from the door of the container, and about $1.65 \mathrm{~m}$ above ground. The external pressure sensors were mounted on skimmer plates oriented perpendicular to the blast front, measuring side-on pressures.

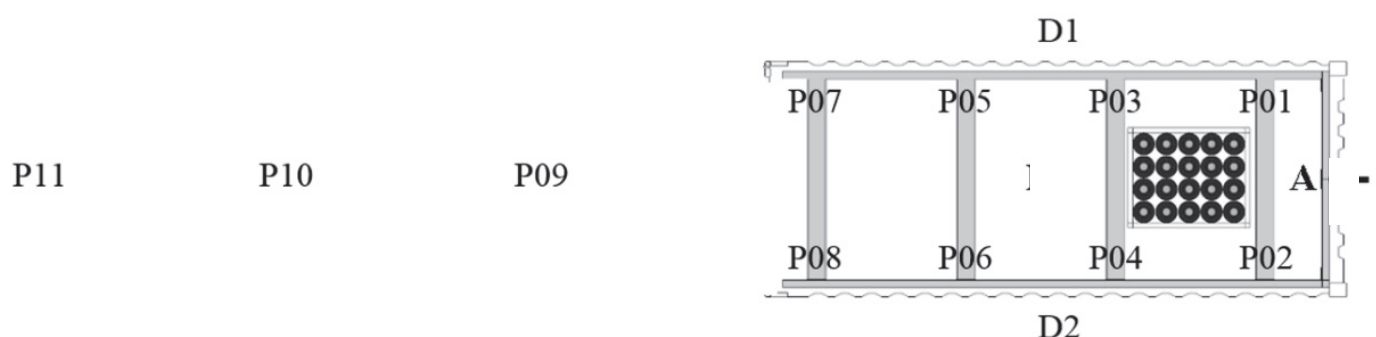

Figure 8: Positions for pressure (P01-P11) and deflection (D1-D2) sensors.

Two Acuity AR700-50 Laser displacement sensors (D1 and D2) measured the dynamic deflection of the container walls. The lasers were operated at around $10 \mathrm{kHz}$, and measured the displacement of the container wall at the centre of the side walls. The explosion events were recorded with two Edgertronic SC1 high-speed cameras and one regular JVC GZ-RX515BE video camera. Four NI-9215 (BNC) C series voltage input modules from National Instruments recorded the signals from the pressure and deflection sensors at a sampling frequency of $100 \mathrm{kHz}$. The results from the first tests revealed significant challenges with noise and drift for the pressure measurements. The noise was gradually reduced by replacing cables and modifying other parts of the measurement system, and the recorded data were smoothed with a Savitzky-Golay filter [4]. Oscillations associated with alternating current at the frequency of the mains electricity $(50 \mathrm{~Hz})$ were processed with a digital filter, and the filtered data were used for data series where visual inspection of the plotted data and a frequency spectrum generated by fast Fourier transform (FFT) showed that the filtering had the desired effect. There is significant uncertainty associated with noise and drift in the signals, and several pressure measurements were discarded during the processing of data (Table 2).

\section{$2.4 \quad$ Test matrix}

Table 1 summarizes the experimental conditions and the maximum overpressures $P_{\text {red, max }}$ recorded in the tests. The container doors were fully open, positioned perpendicular to the sidewalls of the container, and the door opening was covered with plastic film held in place by wooden boards and clamps. The fact that the same container was used in all six tests influences the repeatability of the experiments, especially with respect to the measurements of structural response.

Table 1: Summary of the experiments performed for the first HySEA blind-prediction study.

\begin{tabular}{|c|c|c|c|c|c|}
\hline Configuration & Test no. & $A_{\mathrm{v}}\left(\mathrm{m}^{2}\right)$ & {$\left[\mathrm{H}_{2}\right](\mathrm{vol} . \%)$} & Ign. pos. & $P_{\text {red, } \max }$ (bar) \\
\hline \multirow{3}{*}{$\begin{array}{l}\text { - Frame only }(\mathrm{FO}) \text {, doors open }(\mathrm{O}) \\
\text { - } \\
\text { - } \quad \text { Igniture: } 15.0 \pm 0.2 \text { vol. } \% \text { hydrogen in air back wall }\end{array}$} & 01 & \multirow{3}{*}{5.64} & \multirow{3}{*}{$15.0 \pm 0.2$} & \multirow{3}{*}{ A } & 0.040 \\
\hline & 02 & & & & 0.047 \\
\hline & 05 & & & & 0.039 \\
\hline \multirow{3}{*}{$\begin{array}{ll}\text { - } & \text { Bottle basket (B1), doors open }(\mathrm{O}) \\
\text { - } & \text { Mixture: } 15.0 \pm 0.2 \text { vol. } \% \text { hydrogen in air } \\
\text { - } & \text { Ignition at back wall }\end{array}$} & 03 & \multirow{3}{*}{5.64} & \multirow{3}{*}{$15.0 \pm 0.2$} & \multirow{3}{*}{ A } & 0.077 \\
\hline & 04 & & & & 0.063 \\
\hline & 06 & & & & 0.045 \\
\hline
\end{tabular}




\section{EXPERIMENTAL RESULTS}

Table 2 lists the maximum pressures and wall displacements from the six experiments. NaN (not a number) indicates that the result for a sensor was inconclusive due to drift or noise, and bold font indicates the sensors that measured the highest pressures in each test. Although there is significant uncertainty associated with the measurements from sensors P03-P08 inside the container, the tendency towards lower pressures closer to the vent opening is consistent for all tests.

Table 2: Maximum overpressures P01-P11 (bar) and maximum wall displacements D1-D2 (m).

\begin{tabular}{|c|c|c|c|c|c|c|c|c|c|c|c|c|c|}
\hline Test & P01 & P02 & P03 & P04 & P05 & P06 & P07 & P08 & P09 & P10 & P11 & D1 & D2 \\
\hline 1 & 0.039 & $\mathbf{0 . 0 4 0}$ & 0.026 & 0.031 & 0.018 & 0.021 & NaN & 0.015 & 0.007 & 0.004 & 0.002 & 0.020 & 0.016 \\
\hline 2 & 0.045 & $\mathbf{0 . 0 4 7}$ & $\mathrm{NaN}$ & $\mathrm{NaN}$ & 0.039 & 0.031 & $\mathrm{NaN}$ & 0.023 & 0.012 & 0.005 & 0.003 & 0.041 & 0.042 \\
\hline 5 & $\mathbf{0 . 0 3 9}$ & 0.038 & $\mathrm{NaN}$ & $\mathrm{NaN}$ & $\mathrm{NaN}$ & $\mathrm{NaN}$ & $\mathrm{NaN}$ & $\mathrm{NaN}$ & $\mathrm{NaN}$ & 0.002 & 0.001 & 0.020 & 0.015 \\
\hline 3 & 0.075 & $\mathbf{0 . 0 7 7}$ & $\mathrm{NaN}$ & $\mathrm{NaN}$ & 0.064 & $\mathrm{NaN}$ & 0.033 & 0.040 & 0.024 & 0.012 & 0.009 & 0.105 & 0.086 \\
\hline 4 & 0.062 & $\mathbf{0 . 0 6 3}$ & $\mathrm{NaN}$ & $\mathrm{NaN}$ & 0.058 & 0.064 & $\mathrm{NaN}$ & $\mathrm{NaN}$ & 0.014 & 0.007 & 0.005 & 0.075 & 0.052 \\
\hline 6 & $\mathbf{0 . 0 4 5}$ & 0.044 & 0.039 & 0.034 & $\mathrm{NaN}$ & $\mathrm{NaN}$ & $\mathrm{NaN}$ & $\mathrm{NaN}$ & 0.013 & 0.016 & 0.004 & 0.036 & 0.028 \\
\hline
\end{tabular}

Figure 9 summarizes the results from the six tests, with empty enclosure tests on the left (01: red, 02 : green and 05: blue), and tests with the bottle basket obstacle on the right (03: red, 04: green and 06: blue). The symbols $\square, \Delta$ and $\circ$ represent the maximum values for the smoothed signals. Due to the uncertainty in the measurements for sensors P03-P08, Figure 9 shows the pressure-time curves for P01 and $\mathrm{P} 02$, where special signal cables from Kistler were used in all tests. The problem with drift is evident from the fact that some pressure traces do not return to ambient pressure. The symbols ' + ', ' $x$ ' (internal) and '*' (external) indicate the maximum pressures recorded by the other sensors.
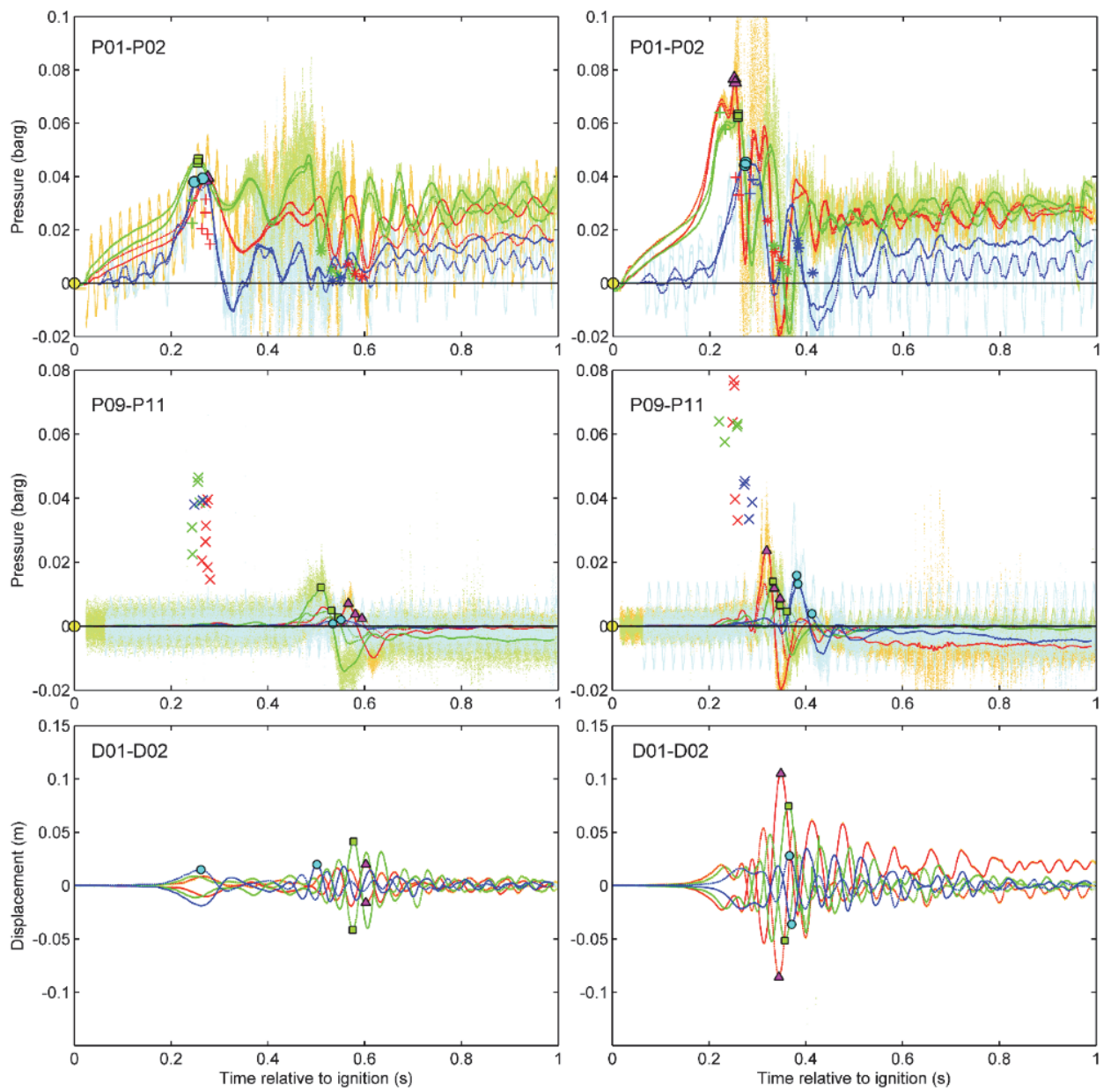

Figure 9: Summary of experimental results for tests 01, 02 and 05 (left) and 03, 04 and 06 (right). 
The results summarised in Figure 9 show that the inclusion of the bottle basket obstacle results in significantly higher explosion pressures. The external pressure sensors P09-P11 show significant variation, but the highest values correspond to the tests that produced the highest internal pressures. In general, the experiments with 15 vol.\% hydrogen resulted in relatively low over-pressures [4-5], and it was necessary to amplify the signals from the pressure sensors significantly. This resulted in low signalto-noise ratios for the measurements. There is significant spread in the results from the displacement measurements as well. The first pressure peaks inside the containers results in similar initial deflections of the walls for the two scenarios, followed by oscillations at a frequency of about $16 \mathrm{~Hz}$. Figure 10 shows frequency spectra for the smoothed and resampled data series. The corresponding peaks in the spectra for internal pressures (P01-P08) and wall deflections (D1-D2) indicate that the pressure fluctuations are coupled to the movement of the walls and the roof of the container. With respect to repeatability and consistency of results, especially for measurements of wall deflection, it is important to consider the inherent uncertainty resulting from using the same container in several consecutive tests.
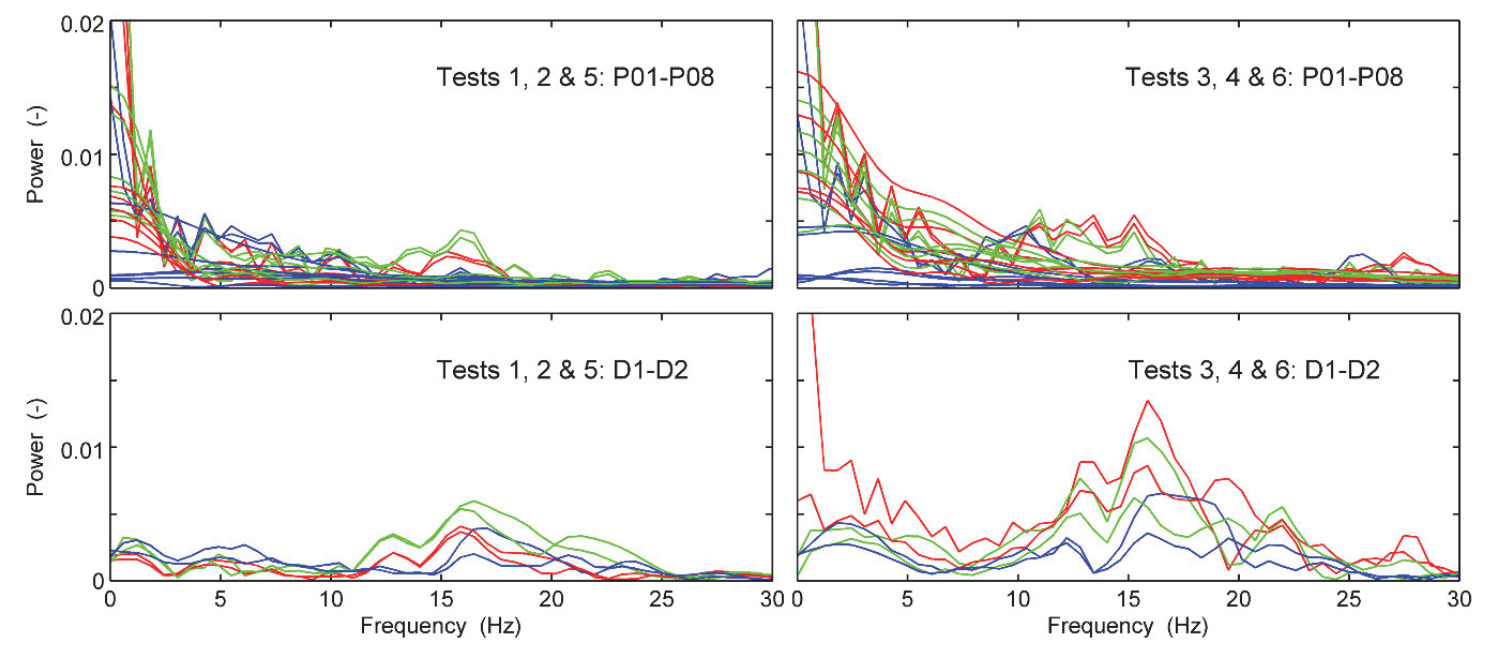

Figure 10: Frequency spectra for smoothed resampled data.

\section{MODEL PREDICTIONS}

\subsection{Consequence models}

University of Pisa received predictions from twelve modellers, or groups of modellers, within the submission deadline: 11 CFD tools and one phenomenological model. One of the CFD predictions was later withdrawn. In addition, several individuals contributed with predictions according to EMs. These predictions were not part of the original blind-prediction study, but the results are nevertheless relevant with respect to the objectives of the HySEA project. Table 3 summarises the engineering models.

Table 3: Engineering models represented in the study.

\begin{tabular}{|l|l|l|}
\hline Correlation & Reference & Modeller \\
\hline NFPA-68 & NFPA-68 [3] & Calculation by C.R. Bauwens (FM Global) \& D. Miller (Air Products) \\
\hline EN 14994 & EN 14994 [2] & Calculation by K. van Wingerden (Gexcon) using $K_{\mathrm{G}}$ values [12] \\
\hline FM Global & {$[13-15]$} & Calculation by C.R. Bauwens (FM Global) \\
\hline FM Global & {$[13-17]$} & Calculation by S. Jallais (Air Liquide) \\
\hline Molkov (1999) & {$[18]$} & Calculation by S. Jallais (Air Liquide) \\
\hline Molkov (2011) & {$[19]$} & Calculation by C.R. Bauwens (FM Global) \\
\hline Molkov (2013-I) & {$[20-21]$} & Calculation by J. Hoyes (HSL) \\
\hline Molkov (2013-II) & {$[20-21]$} & Calculation by J. Hoyes (HSL) \\
\hline
\end{tabular}

Comments: Molkov (2013-I) is a 'best fit' prediction, and Molkov (2013-II) is a conservative prediction. 
Table 4 summarizes the CFD, FE and phenomenological models used for the 11 regular submissions to the blind-prediction study, including brief descriptions of the various models and the approach adopted by the modellers. For the sake of brevity, the model descriptions focus on version numbers and grid resolution. Technical details are available in user manuals and other publications. Only two modelling groups submitted predictions for the maximum deflection of the container walls: M-04 and M-05.

Table 4: Overview of the CFD, FE and phenomenological models used in the blind-prediction study.

\begin{tabular}{|c|c|}
\hline Model & Model description \\
\hline M-01 & FLACS v10.4 with grid resolutions $0.5 \mathrm{~m}$ (frame only) and $0.2 \mathrm{~m}$ (frame with bottle basket obstacle). \\
\hline M-02 & FLACS v10.4 with grid resolutions $0.18 \mathrm{~m} \mathrm{(a)} \mathrm{and} 0.06 \mathrm{~m}$ (b) for both scenarios. \\
\hline M-03 & $\begin{array}{l}\text { Fluidyn with grid resolution } 0.04 \mathrm{~m}, \mathrm{SST}-\mathrm{k}-\Omega \text { turbulence model, and additional solver settings: } \\
\text { - The model assumes viscous unsteady flow and accounts for in the effect of temperature on } \\
\text { - } \quad \text { Mecific heat, viscosity, thermal conductivity and mass diffusivity. } \\
\text { - } \quad \text { Maximum computational time step } 0.0005 \mathrm{~s} \text {. }\end{array}$ \\
\hline M-04 & $\begin{array}{l}\text { FLACS v10.5 with grid resolution } 0.12 \mathrm{~m} \text { ( } 0.06 \mathrm{~m} \text { tested, with consistent results). } \\
\text { Structural response analysis performed with the IMPETUS Afea Solver: } \\
\text { - Material model taken from internal library based on DNV-RP-C208 and } 355 \text { grade steel. } \\
\text { - Four individual load curves imported from FLACS (one-way coupling and symmetry plane): } \\
\text { internal side wall, back wall, roof and ceiling. } \\
\text { - Doors not included in these simulations, and the bottom corners were fixed. }\end{array}$ \\
\hline M-05 & $\begin{array}{l}\text { FLACS v10.4 with grid resolution of } 0.06 \mathrm{~m}(0.12 \mathrm{~m} \text { tested, with consistent results). } \\
\text { - Sensitivity studies showed that the effect of geometry details, including corrugated walls, had } \\
\text { limited impact on the results. } \\
\text { - Assumed initial temperature of } 15^{\circ} \mathrm{C} \text { and applied PLANE_WAVE boundary conditions, } \\
\text { otherwise standard settings for FLACS simulations. } \\
\text { Maximum wall deflection estimated from pressure loads calculated with FLACS using static deflection } \\
\text { formulas, assuming the Eigen period is much shorter than } 50 \mathrm{~ms} \text { (i.e. Eigen frequency }>>20 \mathrm{~Hz}) \text {. }\end{array}$ \\
\hline M-06 & $\begin{array}{l}\text { KFX-Exsim with automatic grid generation }(\mathrm{a}: 0.3 \mathrm{~m}) \text {, and resubmitted (i.e. not blind-prediction) with } \\
\text { updated grid resolution according to guidelines }(\mathrm{b}: 0.15 \mathrm{~m}) .\end{array}$ \\
\hline M-07 & $\begin{array}{l}\text { CFX v17.0 with grid resolutions } 0.15 \mathrm{~m}(\mathrm{a}), 0.10 \mathrm{~m}(\mathrm{~b}) \text { and } 0.05 \mathrm{~m}(\mathrm{c}) \text { for both scenarios, } \mathrm{k}-\varepsilon \text { turbulence } \\
\text { model, and additional solver settings: } \\
\text { - Combustion model based on Zimont turbulent flame speed closure with artificially high levels of } \\
\text { initial turbulence. } \\
\text { - High resolution scheme for spatial discretisation and second order backward Euler scheme for } \\
\text { temporal discretisation. } \\
\text { - On the advice of ANSYS, the previous timestep option was used to initialise the next timestep. }\end{array}$ \\
\hline M-08 & $\begin{array}{l}\text { Explicit HLLC hydrodynamic solver with grid resolution } 0.02 \mathrm{~m} \text { for both scenarios, with standard k- } \varepsilon \\
\text { turbulence model, CFL }=0.9 \text {, and additional solver settings: } \\
\text { - } \quad \text { Equidistant uniform mesh with } 927 \times 303 \times 255 \text { cells. } \\
\text { - } \quad \text { Integral combustion model KYLCOM. } \\
\text { - } \quad \text { Activated models for thermo-diffusive and Rayleigh-Taylor instability. }\end{array}$ \\
\hline M-09 & EXPRES (phenomenological model developed for confined and external explosions) \\
\hline M-10 & FLACS v10.2 with grid resolutions $0.2 \mathrm{~m}(\mathrm{a}), 0.1 \mathrm{~m}(\mathrm{~b}), 0.05 \mathrm{~m}(\mathrm{c})$ and $0.025 \mathrm{~m}(\mathrm{~d})$. \\
\hline M-11 & $\begin{array}{l}\text { ADREA-HF CFD code with grid resolution } 0.1 \mathrm{~m} \text { following the LES method for turbulence and } \\
\text { additional solver settings: } \\
\text { - Multi-phenomena turbulent burning velocity combustion model proposed by Molkov et al. } \\
\text { - Turbulent burning velocity calculated with a modified version of the Yakhot equation. } \\
\text { - No special modelling of the external explosion. }\end{array}$ \\
\hline
\end{tabular}




\subsection{Model results}

Figures 11 and 12 compare the experimental and predicted pressure-time histories for pressure sensors P01 for the models in Table 4. Figures 13 and 14 show the corresponding scatter plots for all internal sensors (i.e. P01-P09). The green and blue dotted lines in the scatter plots represent deviations of $\pm 30 \%$ and $\pm 100 \%$ (i.e. a factor two discrepancy), respectively.
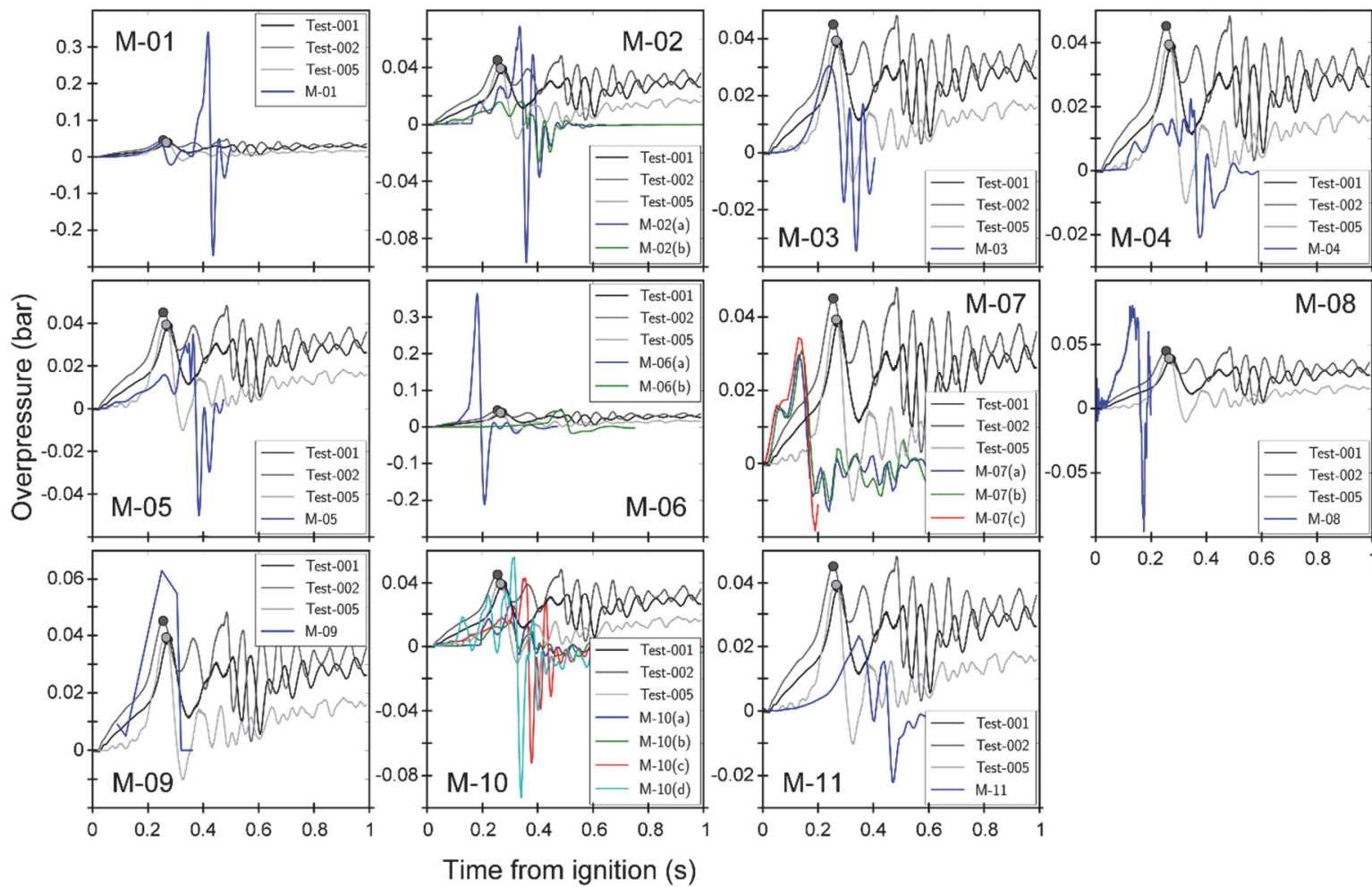

Figure 11: Pressure-time histories for sensor P01 for tests 01, 02 and 05 (frame only).
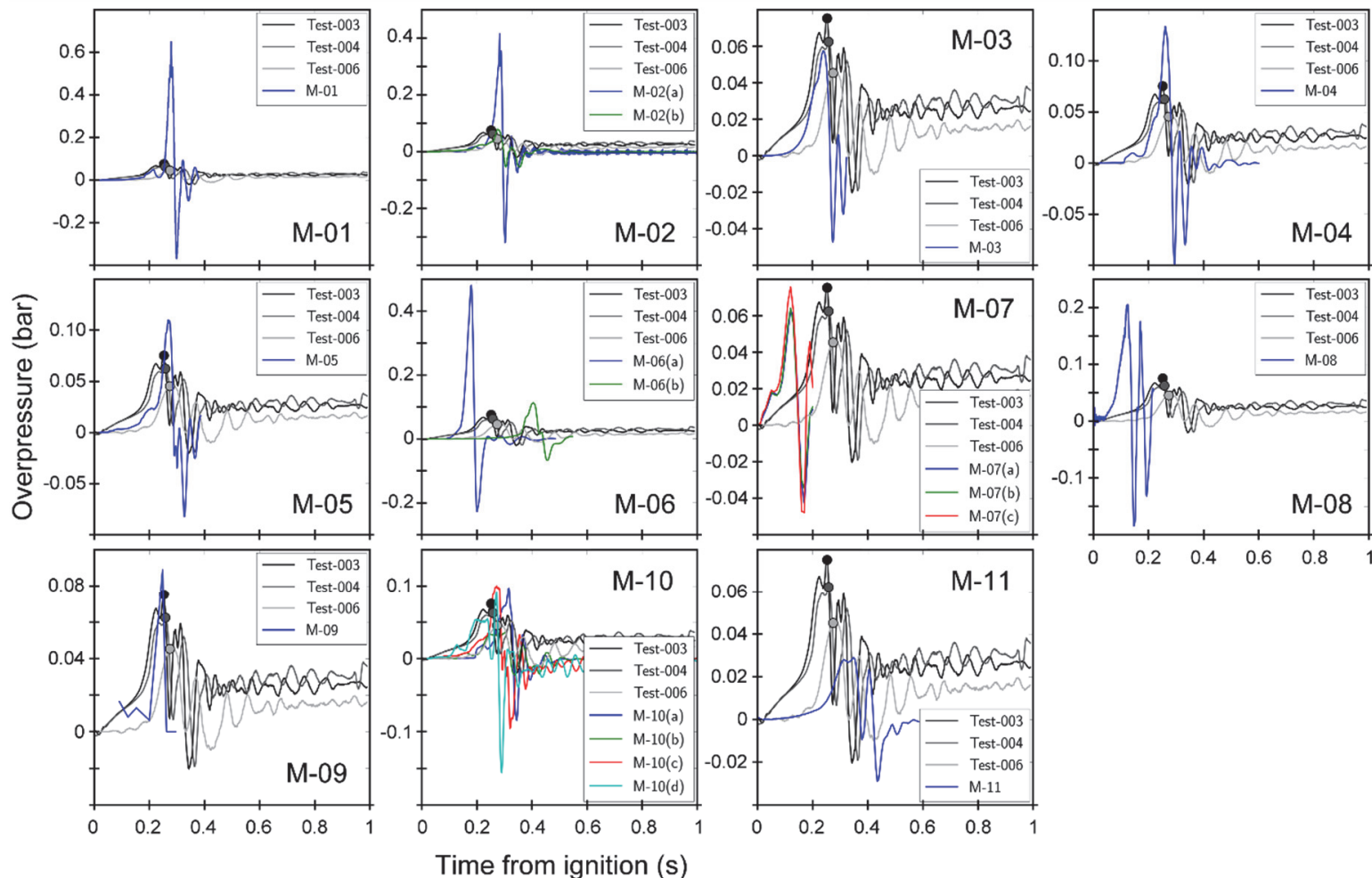

Figure 12: Pressure-time histories for sensor P01 for tests 03, 04 and 06 (frame with bottle basket). 


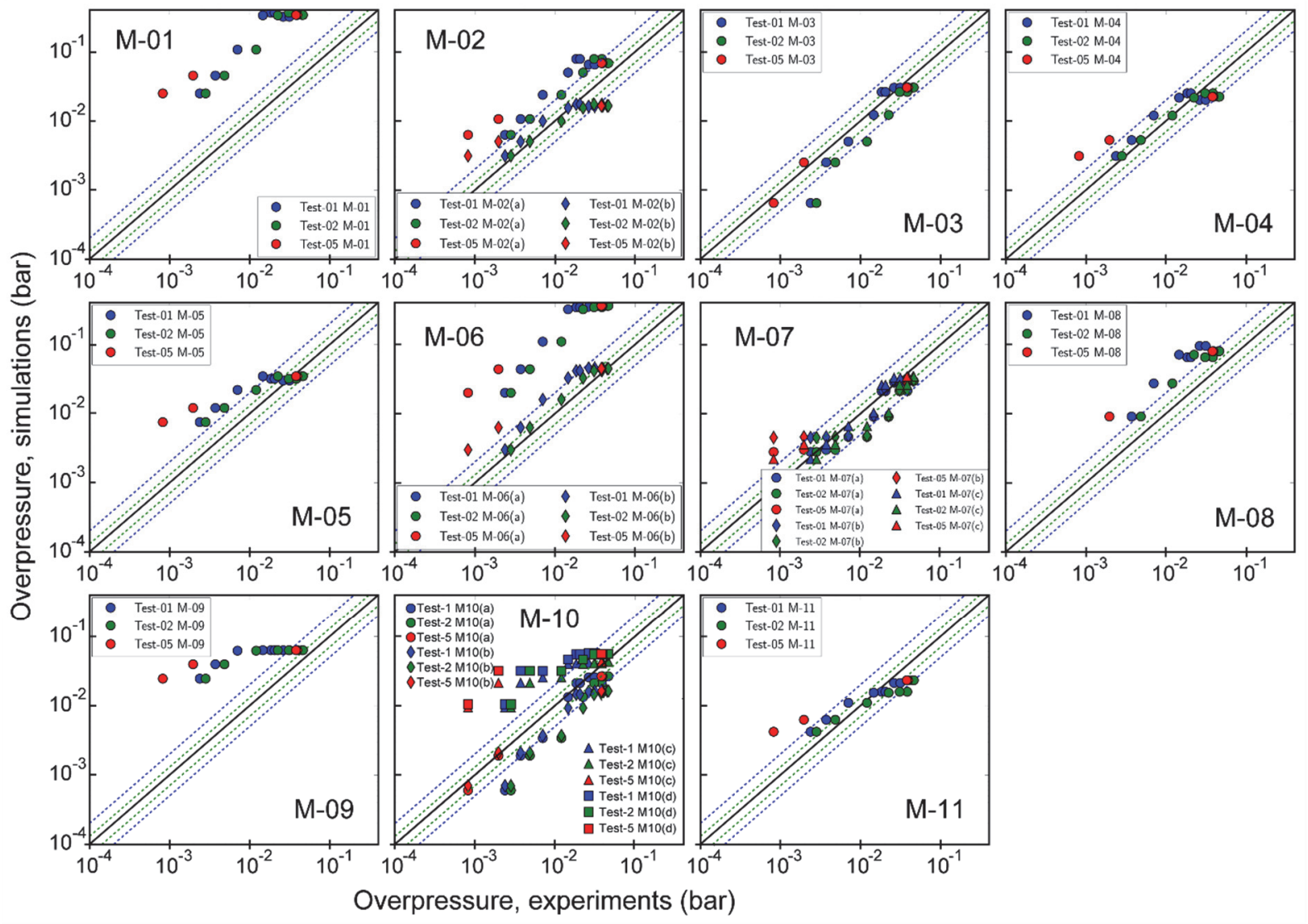

Figure 13: Simulated vs. experimental explosion pressures for tests 01, 02 and 05 (frame only).

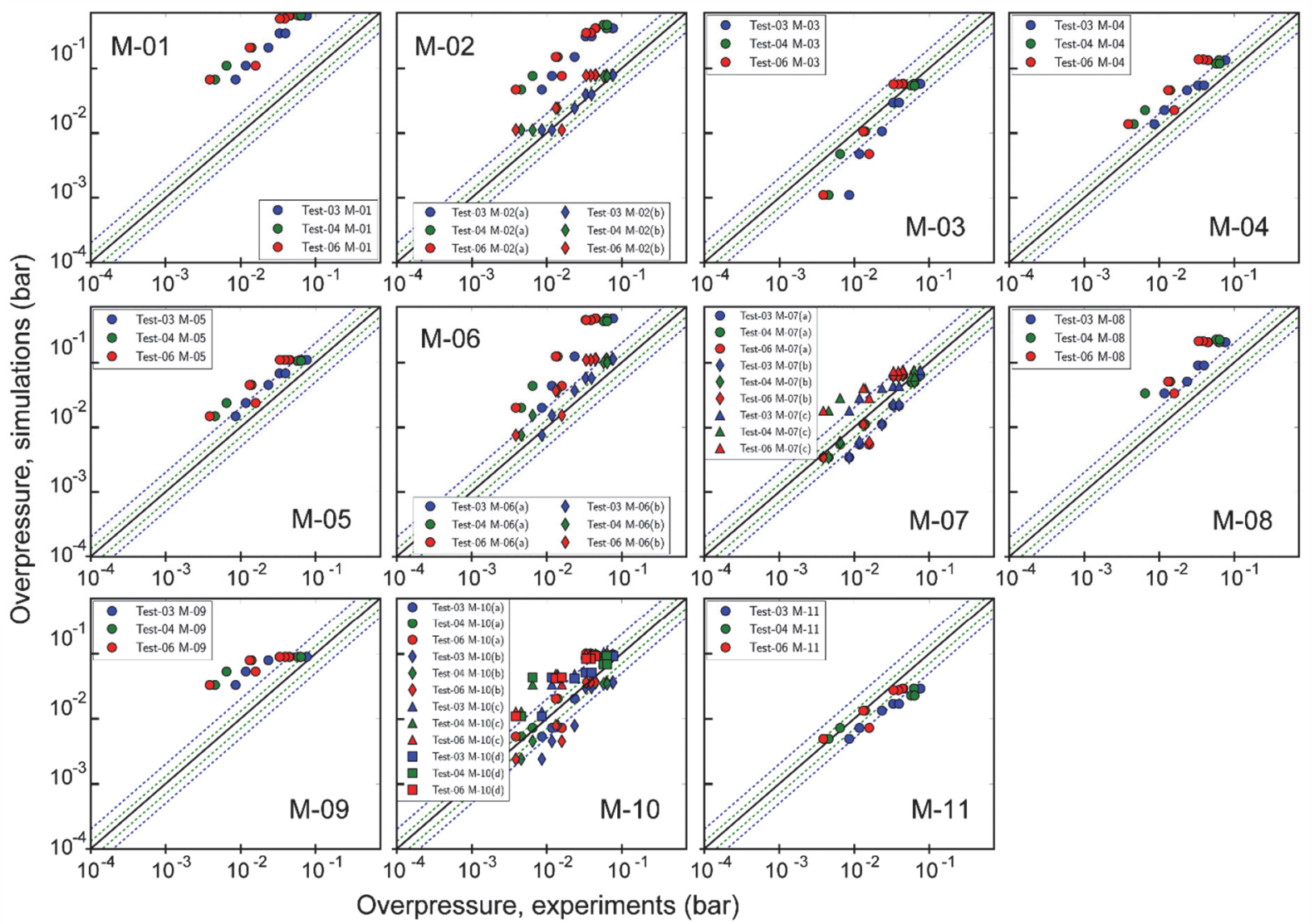

Figure 14: Simulated vs. experimental explosion pressures for tests 03, 04 and 06 (frame with bottles). 


\section{DISCUSSION}

Figure 15 summarises the results for the maximum overpressure predictions from the CFD tools and the phenomenological model (M-09). The shaded region indicates the spread in the experimental results. Most of the model predictions agree reasonably well with the experimental results, and all models capture the increase in pressure when the bottle basket obstacle is introduced. However, the ratios between the highest and lowest predictions are about 23 for both scenarios, indicating significant limitations in predictive capabilities. The large scatter in results for the same CFD tool (M-01, M-02, M-04, M-05 and M-10), for different users and grid resolutions, highlights the need for revised user guidelines and automated settings that may improve both user-friendliness and predictability. It is not straightforward to determine whether this variation in results from different users of the software also applies to other models, since none of the other CFD tools were represented with predictions from more than one modeller or group of modellers. The results for M-06 illustrate the effect of misinterpreting the grid guidelines, where in this case the automatically generated grid should have been refined by a factor two for explosions in a confined space (Table 4).

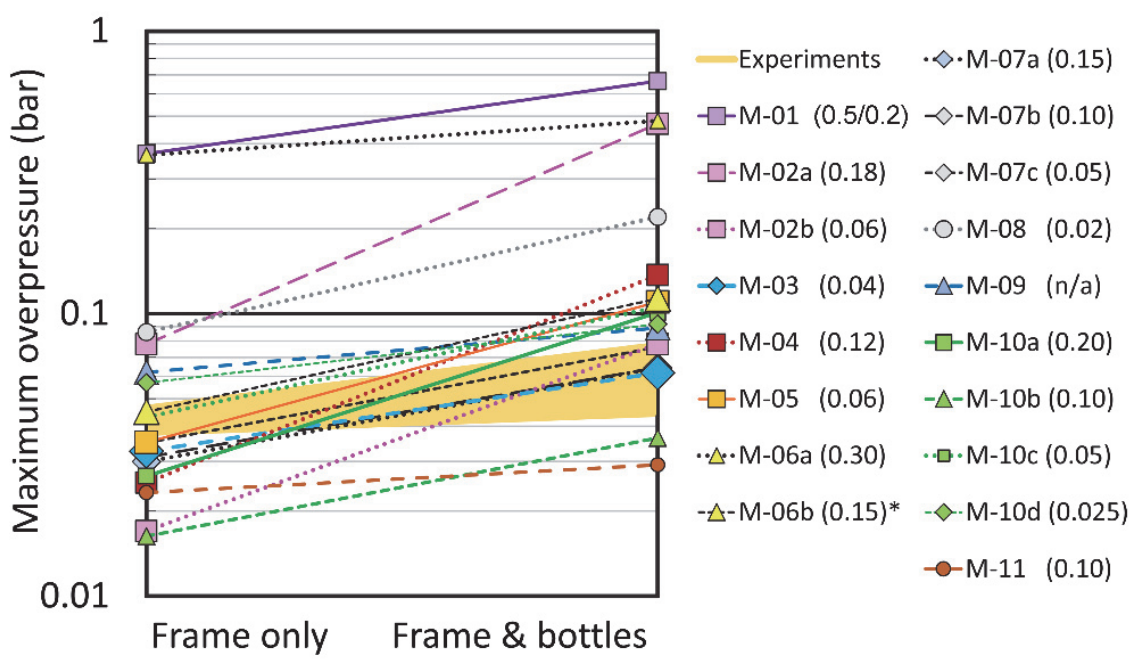

Figure 15: Comparison of model predictions for advanced consequence models.

Figure 16 summarises the results for the engineering models, where the ratios between the highest and lowest predictions are less than 10. Since the scenarios selected for the first blind-prediction study involved relatively simple geometries, it is not surprising that the empirical models perform quite well. The difference between the predictions by the FM Global model is the treatment of the bottle basket obstacle as one single obstacle (1-obst.) vs. multiple bottles (m-obst.). The prediction based on the single-obstacle assumption follows the trend in the experimental data closer than the other models that include the effect of the obstacle - five of the nine engineering models do not.

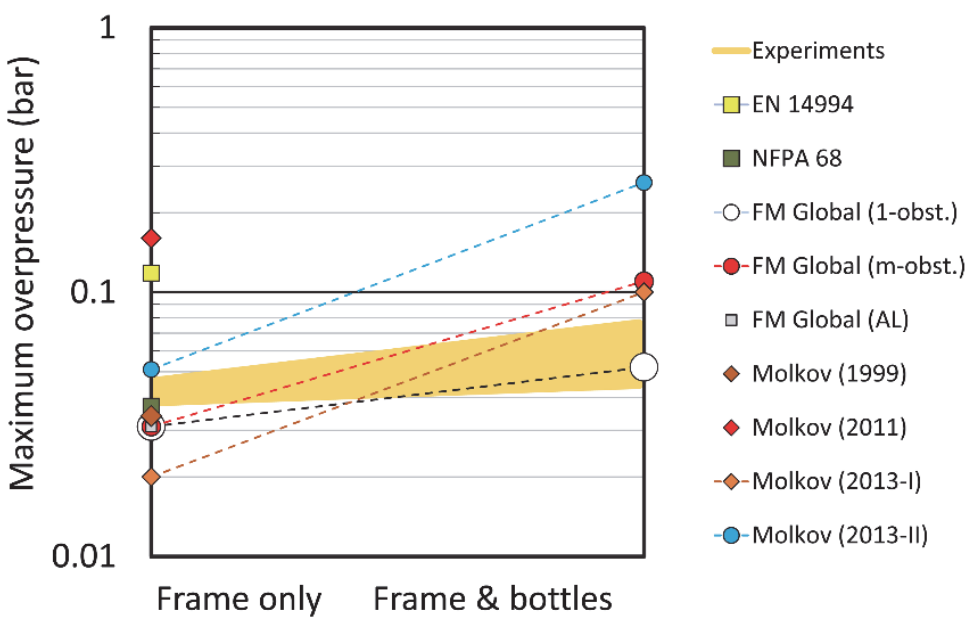

Figure 16: Comparison of model predictions for engineering models. 
Figure 17 summarizes the results from the structural response calculations. Only two groups submitted predictions for the maximum deflection of the container walls: M-04 used pressure-time data from FLACS as input to structural response calculations with the IMPETUS Afea Solver, and M-05 used similar data from FLACS combined with a simplified approach based on static deflection formulas. The relatively low deflection in test 06 (Figure 9) is the main reason for the larger scatter for the scenario with the bottle basket obstacle, compared to frame only. The experimental results indicate that the maximum deflection is caused by a resonance phenomenon, where pressure oscillations reinforce oscillations in the walls of the containers at a frequency of about $16 \mathrm{~Hz}$ (Figure 10). Furthermore, the dynamic response of the walls and the oscillations of the roof are strongly coupled, and only the FE model (M-04) is able to capture this effect.

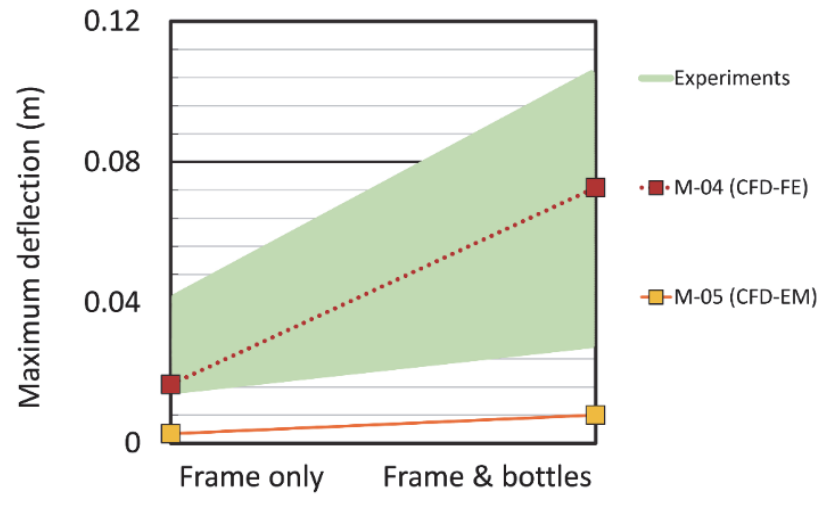

Figure 17: Comparison of model predictions for maximum deflection.

\section{CONCLUSIONS AND FURTHER WORK}

The first blind-prediction study in the HySEA project explored two explosion scenarios in 20-foot ISO containers: homogeneous 15 vol.\% hydrogen-air mixtures, ignited to deflagration by a spark plug at the back wall of the container, and vented through the open doors of the container, with or without a bottle basket obstacle installed inside the container. The test program included three repetitions for each scenario. The lean mixtures and simple geometry configuration resulted in relatively weak explosions and modest effects of the obstacle. The comparison between experimental data and model predictions revealed good agreement for some models, and significant under-prediction or over-predictions for others. The engineering models performed overall better than the more advanced consequence models for this type of scenarios. This might not be the case for more complex scenarios and/or a wider selection of engineering models.

The results from the blind-prediction study has resulted in increased awareness amongst modellers, as well as updated guidelines for users of some of the advanced consequence models. Further work in the HySEA project will focus on validating engineering models and CFD tools against results from a wide range of experiments, including more violent explosions and more complex geometries. The second blind-prediction study will focus on deflagrations in inhomogeneous mixtures in 20-foot ISO containers.

\section{DISCLAIMER}

A part of this work was co-funded by the Health and Safety Executive (HSE). The contents of the publication, including any opinions and/or conclusions expressed are those of the authors alone and do not necessarily reflect HSE policy. The same applies to the contributions from the other organizations.

\section{ACKNOWLEDGEMENTS}

The HySEA project receives funding from the Fuel Cells and Hydrogen 2 Joint Undertaking under grant agreement No. 671461. This Joint Undertaking receives support from the European Union's Horizon 2020 research and innovation programme and United Kingdom, Italy, Belgium and Norway. The partners in the HySEA consortium gratefully acknowledge the contributions from all the modellers. 


\section{REFERENCES}

1. Skjold, T., Siccama, D., Hisken, H., Brambilla, A, Middha, P., Groth, K.M. \& LaFleur, A.C., 3D risk management for hydrogen installations, International Journal of Hydrogen Energy, 42, 2017, pp. 7721-7730.

2. EN 14994, Gas explosion venting protective systems, 2007, European Committee for Standardization (CEN), Brussels, Belgium, $30 \mathrm{pp}$.

3. NFPA 68, Standard on explosion protection by deflagration venting, 2013, National Fire Protection Association (NFPA), Quincy, Massachusetts, USA.

4. Skjold, T., Lakshmipathy, S., van Wingerden, M., Hisken, H., Atanga, G., Olsen, K.L., Holme, M.N., Turøy, N.M., Mykleby, M. \& van Wingerden, K., Experimental investigation of vented hydrogen deflagrations in containers - Phase 1, 2017, Report HySEA-D2-04-2017.

5. Skjold, T., Hisken, H., Lakshmipathy, S., Atanga, G., van Wingerden, M., Olsen, K.L., Holme, M.N., Turøy, N.M., Mykleby, M \& van Wingerden, K., Influence of congestion on vented hydrogen deflagrations in 20-foot ISO containers: homogeneous fuel-air mixtures, Twenty-Sixth International Colloquium on the Dynamics of Explosions and Reactive Systems (ICDERS), Boston, 30 July - 4 August 2017, 6 pp.

6. Sommersel, O.K., Bjerketvedt, D, Christensen, S., Krest, O. \& Vaagsaether, K., Application of background oriented Schlieren for quantitative measurements of shock waves from explosions, Shock Waves, 18, 2008, pp. 291-297.

7. Sommersel, O.K., Vaagsaether, K. \& Bjerketvedt, D., Hydrogen explosions in $20^{\prime}$ ISO container, International Journal of Hydrogen Energy, 42, 2017, pp. 7740-7748.

8. Baraldi, D., Kotchourko, A., Lelyakin, A., Yanez, J., Gavrikov, A., Efimenko, A., Verbecke, F., Makarov, D., Molkov, V. \& Teodorczyk, A., An inter-comparison exercise on CFD model capabilities to simulate hydrogen deflagrations with pressure relief vents, International Journal of Hydrogen Energy, 35, 2010, pp. 12381-12390.

9. Baraldi, D., Melideo, D., Kotchourko, A., Ren, K., Yanez, J., Jedicke, O., Giannissi, S.G., Tolias, I.C., Venetsanos, A.G., Keenan, J., Makarov, D., Molkov, V., Slater, S., Verbecke, F. \& Duclos, A., Development of a model evaluation protocol for CFD analysis of hydrogen safety issues the SUSANA project, International Journal of Hydrogen Energy, 42, 2017, pp. 7633-7643.

10. García, J., Baraldi, D., Gallego, E., Beccantini, A., Crespo, A., Hansen, O.R., Høiset, S., Kotchourko, A., Makarov, D., Migoya, E., Molkov, V., Voort, M.M. \& Yanez, J., An intercomparison exercise on the capabilities of CFD models to reproduce a large-scale hydrogen deflagration in open atmosphere, International Journal of Hydrogen Energy, 35, 2010, pp. 44354444.

11. Makarov, D., Verbecke, F., Molkov, V., Roe, O., Skotenne, M., Kotchourko, A., Lelyakin, A., Yanez, J., Hansen, O., Middha, P., Ledin, S., Baraldi, D., Heitsch, M., Efimenko, A. \& Gavrikov, A., An inter-comparison exercise on CFD model capabilities to predict a hydrogen explosion in a simulated vehicle refuelling environment, International Journal of Hydrogen Energy, 34, 2009, pp. 2800-2814.

12. Holtappels, K., Report on the experimentally determined explosion limits, explosion pressures and rates of explosion pressure rise, Part 1: methane, hydrogen and propylene, SAFEKINEX Project Deliverable No. 8, 2006, Federal Institute for Materials Research and Testing (BAM), Germany, $149 \mathrm{pp}$.

13. Bauwens, C.R., Chaffee, J. \& Dorofeev, S.B., Effect of ignition location, vent size, and obstacles on vented explosion overpressures in propane-air mixtures, Combustion Science and Technology, 182, 2010, pp. 1915-1932.

14. Bauwens, C.R., Chao, J. \& Dorofeev, S.B., Evaluation of a multi peak explosion vent sizing methodology, Ninth International Symposium on Hazard, Prevention and Mitigation of industrial Explosions (ISHPMIE), Krakow, 22-27 July 2012, 20 pp.

15. Chao, J., Bauwens, C.R. \& Dorofeev, S.B., An analysis of peak overpressures in vented gaseous explosions, Proceedings of the Combustion Institute, 33, 2011, pp. 2367-2374. 
16. Jallais, S. \& Kudriakov, S., An inter-comparison exercise on engineering models capabilities to simulate hydrogen vented explosions, Fifth International Conference on Hydrogen Safety (ICHS), Brussels, 9-13 September 2013, 13 pp.

17. Vyazmina, E. \& Jallais, S., Validation and recommendations for FLACS CFD and engineering approaches to model hydrogen vented explosions: effect of concentration, obstruction vent area and ignition position, International Journal on Hydrogen Energy, 33, 2016, pp. 15101-15109.

18. Molkov, V., Dobashi, R., Suzuki, M. \& Hirano, T., Modeling of vented hydrogen-air deflagrations and correlations for vent sizing, Journal of Loss Prevention in the Process Industries, 12, 1999, pp. 147-156.

19. Molkov, V., Primer "Hydrogen deflagrations", presentation Joint Summer School on Fuel Cell and Hydrogen Technology, 21-25 August 2011, Viterbo, Italy.

20. Molkov, V. \& Bragin, M., Hydrogen-air deflagrations: vent sizing correlation for low-strength equipment and buildings, Fifth International Conference on Hydrogen Safety (ICHS), 9-11 September 2013, Brussels, Belgium, 13 pp.

21. Molkov, V. \& Bragin, M., Hydrogen-air deflagrations: vent sizing correlation for low-strength equipment and buildings, International Journal of Hydrogen Energy, 40, 2015, pp. 1256-1266. 